Table 1. Employment status of Spanish Atlas survey respondents

\begin{tabular}{|c|c|c|c|c|c|}
\hline Population & $\mathrm{N}$ & $\%$ & Employment status & $\mathrm{N}$ & $\%$ \\
\hline \multirow[t]{3}{*}{ Active population* } & 415 & 63.6 & Employed & 325 & 78.3 \\
\hline & & & Unemployed & 90 & 21.6 \\
\hline & & & Total & 415 & 100.0 \\
\hline \multirow{7}{*}{ Inactive population } & 238 & 36.4 & Temporary sick leave & 63 & 26.5 \\
\hline & & & Permanent sick leave & 64 & 26.9 \\
\hline & & & Retired & 63 & 26.5 \\
\hline & & & Homemakers & 29 & 12.2 \\
\hline & & & Students & 9 & 3.8 \\
\hline & & & Early retirement & 10 & 4.2 \\
\hline & & & Total & 238 & 100.0 \\
\hline Total & 653 & 100.0 & & & \\
\hline
\end{tabular}

${ }^{*}$ According to the ILO

Table 2. Association between sociodemographic characteristics and PROs comparing employed and unemployed axSpA patients

\begin{tabular}{|c|c|c|c|}
\hline & $\begin{array}{c}\text { Employed } \\
(\mathrm{N}=325) \\
\text { Mean } \pm \mathrm{SD} \text { or } \mathrm{n}(\%)\end{array}$ & $\begin{array}{c}\text { Unemployed } \\
(\mathrm{N}=90) \\
\text { Mean } \pm \mathrm{SD} \text { or } \mathrm{n}(\%)\end{array}$ & p-value \\
\hline \multicolumn{4}{|l|}{ Sociodemographic } \\
\hline Age (years) & $42.9 \pm 8.6$ & $42.0 \pm 9.1$ & 0.513 \\
\hline Gender (Male) & $159(48.9)$ & $36(40.0)$ & 0.133 \\
\hline Education level (University) & $153(47.1)$ & $21(23.3)$ & $0.001^{*}$ \\
\hline Marital status (Married) & $231(71.1)$ & $54(60.0)$ & 0.051 \\
\hline Monthly Income (€) & $890.4 \pm 592.3$ & $358.5 \pm 377.7$ & $<0.001^{*}$ \\
\hline \multicolumn{4}{|l|}{ PROs } \\
\hline Diagnostic Delay (years) & $7.7 \pm 7.6$ & $8.0 \pm 6.5$ & 0.319 \\
\hline BASDAI $(0-10)$ & $5.2 \pm 1.9$ & $6.3 \pm 1.9$ & $<0.001^{*}$ \\
\hline Spinal Stiffness (3-12) & $6.5 \pm 2.6$ & $7.8 \pm 2.3$ & $<0.001^{*}$ \\
\hline Global Limitation Index (0-54) & $40.6 \pm 10.1$ & $45.0 \pm 8.4$ & $<0.001^{*}$ \\
\hline GHQ-12 (0-12) & $4.9 \pm 4.3$ & $7.6 \pm 4.2$ & $<0.001^{*}$ \\
\hline Anxiety & $52(16.0)$ & $25(27.8)$ & $0.011^{*}$ \\
\hline Depression & $33(10.2)$ & $21(23.3)$ & $0.001^{*}$ \\
\hline Sleep disorder & $50(15.4)$ & $18(20.0)$ & 0.295 \\
\hline
\end{tabular}

Conclusion: The Spanish Atlas results show significant differences between employed and unemployed patients with axSpA, with greater disease activity, spinal stiffness, functional limitation, and poorer mental health in those who are unemployed.

Acknowledgments: Funded by Novartis Pharma AG \& Novartis Farmacéutica S.A.

Disclosure of Interests: Marco Garrido-Cumbrera: None declared, Jordi Gratacos-Masmitja Grant/research support from: a grant from Pfizzer to study implementation of multidisciplinary units to manage PSA in SPAIN, Consultant of: Pfizzer, MSD, ABBVIE, Janssen, Amgen, BMS, Novartis, Lilly, Speakers bureau: Pfizzer, MSD, ABBVIE, Janssen, Amgen, BMS, Novartis, Lilly, Eduardo Collantes-Estévez Grant/research support from: ROCHE and Pfizer., Speakers bureau: ROCHE, Lilly, Bristol and Celgene., Pedro Zarco Montejo Grant/research support from: Pfizzer, MSD, ABBVIE, Janssen, Amgen, BMS, Novartis, Lilly, Speakers bureau: Pfizzer, MSD, ABBVIE, Janssen, Amgen, BMS, Novartis, Lilly, Carlos Sastré Employee of: YES; I'm Medical Advisor in Novartis Spain, José Correa-Fernández: None declared, Pedro Plazuelo-Ramos: None declared, Victoria Navarro-Compán Consultant of: Abbvie, Lilly, Novartis, Pfizer, UCB, Speakers bureau: AbbVie, MSD, Lilly, Novartis, Pfizer, UCB DOI: 10.1136/annrheumdis-2020-eular.5728

\section{AB0685 IMPACT OF AXSPA ON WORKING LIFE: RESULTS FROM 233 PATIENTS OF THE RUSSIAN FEDERATION PARTICIPATING IN THE EUROPEAN MAP OF AXIAL SPONDYLOARTHIRTIS (EMAS)}

1. Gaydukova ${ }^{1}$, M. Garrido-Cumbrera ${ }^{2}$, T. Dubinina ${ }^{3}$, A. Dubikov ${ }^{4}$,

E. Zonova ${ }^{5}$, M. Korolev ${ }^{6}$, S. Lapshina ${ }^{7}$, P. Pchelnikova ${ }^{8}$, I. Shipilova ${ }^{9}$,

A. Sitalo ${ }^{10} .{ }^{1}$ North-Western State Medical University n.a. II Mechnikov, St. Petersburg, Russian Federation; ${ }^{2}$ Universidad de Sevilla, Health and Territory Research (HTR), Seville, Spain; ${ }^{3}$ VA Nasonova Research Institute of Rheumatology, Moscow, Russian Federation; ${ }^{4}$ Clinic of rheumatology, Vladivostok, Russian Federation; ${ }^{5}$ Research Institute of Clinical and Experimental Lymphology, Novosibirsk, Russian Federation; ${ }^{6}$ Novosibirsk State Medical University, Novosibirsk, Russian Federation; ${ }^{7}$ Kazan State Medical University, Kazan, Russian Federation; ${ }^{8}$ All-Russian Patient Union, Moscow, Russian Federation; ${ }^{9}$ Novartis Pharma LLC, Moscow, Russian Federation; ${ }^{10}$ Russian Ankylosing Spondylitis Association, Moscow, Russian Federation
Background: Axial spondyloarthritis (axSpA) has been shown to impact patients' (pts) professional opportunities, employment status and work productivity [1]. Objectives: To evaluate employment status, work-related issues and their interrelation with the disease-related characteristics among Russian axSpA pts.

Methods: The European Map of Axial Spondyloarthritis (EMAS) was a cross-sectional on-line survey of pts with self-reported axSpA conducted in 13 European countries. Russian participants were recruited between Dec 2017 and Feb 2018 through the Russian Ankylosing Spondylitis Association and an online panel. Socio-demographic, BASDAl, psychological distress (GHQ-12), working status and work-related issues (e.g. taking sick leave, difficulties fulfilling or reducing working hours, etc.) were assessed.

Results: 233 Russian pts participated in EMAS. The mean age was $36.7 \pm 9.1$ years, $51.9 \%$ were female, and the mean disease duration was $12.4 \pm 9.5$ years Of the 233,226 reported their employment status and productivity, of which $73.45 \%$ were employed, $12.39 \%$ were unemployed, $4.42 \%$ were on sick leave, $3.54 \%$ were homemakers, $2.21 \%$ were retired, $2.21 \%$ were on early retirements, $1.77 \%$ were students. Of the 160 pts, who reported their occupation, $73(45.63 \%)$ were employed and had jobs requiring higher education qualifications, $39(24.38 \%)$ had management positions, $23(14.38 \%)$ were skilled manual workers and $12(7.50 \%)$ were skilled non-manual workers, $3(1.88 \%)$ were occupied in armed forces, $3(1.88 \%)$ pts worked as unskilled workers. 124 (76.54\%) of 162 pts survey respondents declared to have suffered work issues related to their disease in the 12 months prior to the survey. The most common work-related issue was difficulty fulfilling working hours in 69 (56.56\%), followed by taking sick leave $49(40.16 \%)$ and asking for days off $44(36.07 \%)$ out of 122 pts. Pts who reported any type of issues at work had higher BASDA and psychological distress (GHQ-12 score) (table 1). 145 (76.32\%) out of 190 responded pts reported that their choice of workplace had been influenced by the disease $(68.25 \%)$.

Table 1. BASDAI and GHQ-12 by work-related issues and difficulty fulfilling working hours due to axSpA.

\begin{tabular}{lccccccc}
\hline Any type of issue at work & BASDAI & \multicolumn{7}{c}{ GHQ-12 } \\
\hline & Mean & SD & N & Mean & SD & N \\
\hline No & $3.14^{\star}$ & 1.93 & 38 & $2.95^{\star}$ & 3.39 & 38 \\
Yes & $4.97^{\star}$ & 2.08 & 124 & $6.53^{\star}$ & 3.76 & 124 \\
Difficulty fulfilling working hours & Mean & SD & N & Mean & SD & N \\
No & $4.53^{\star *}$ & 2.15 & 55 & $5.49^{\star \star}$ & 3.80 & 55 \\
Yes & $5.32^{\star \star}$ & 1.96 & 69 & $7.36^{\star *}$ & 3.54 & 69 \\
\hline
\end{tabular}

* Mann-Whitney test $p$-values $<0.001$

** Mann-Whitney test $p$-values $<0.05$

Conclusion: Results from the Russian sample of the EMAS survey highlight the impact of axSpA in working life. Patients with any type of work-related issue mark above the cut-off point of BASDAI and GHQ-12, so work-related issues are associated to a status of high disease activity and a risk of poor mental health. Among all work-related issues surveyed, the presence of presenteeism (measured by difficulty fulfilling working hours) is associated to both a clinical and significant increase in disease activity through BASDAI.

References:

[1] van Lunteren, M., et al. https://doi.org/10.1093/rheumatology/kex365.

Disclosure of Interests: Inna Gaydukova Grant/research support from: JSC BIOCAD, Speakers bureau: Pfizer, Novartis, AbbVie, JSC BIOCAD, Celgene, MSD, Sanofi, Marco Garrido-Cumbrera: None declared, Tatiana Dubinina Speakers bureau: Novartis, BIOCAD, MSD, Pfaizer, Abbvie, UCB, Alexander Dubikov: None declared, Elena Zonova Speakers bureau: Pfizer, Abbvie, Bayer, Janssen, Lilly, Maxim Korolev: None declared, Svetlana Lapshina: None declared, Polina Pchelnikova: None declared, Irina Shipilova Employee of: Novartis Pharma LLC, Alexey Sitalo: None declared

DOI: 10.1136/annrheumdis-2020-eular.4875

\section{AB0686 ONLINE QUESTIONNAIRE CAN IMPROVE DELAY IN AXIAL SPONDYLOARTHRITIS DIAGNOSTICS. RESULTS OF SAINT PETERSBURG AXSPA EARLY DIAGNOSTICS PROJECT}

E. Gaydukova ${ }^{1}$, V. Mazurov ${ }^{1,2}$, O. Inamova ${ }^{1,2}$, E. Vasilenko ${ }^{1,2}$, I. Gaydukova $^{1,2}$. ${ }^{1}$ Clinical Rheumatological Hospital №25, St. Petersburg, Russian Federation; ${ }^{2}$ North-Western State Medical University named after I. I. Mechnikov, St. Petersburg, Russian Federation

Background: Due to current data mean diagnostics delay in axial spondyloarthritis $(\mathrm{axSpA})$ is $7.4 \pm 8.4$ years (mean $\pm \mathrm{SD}$ ) [1]. However, development 